\title{
SOMEWHERE OVER THE RAINBOW: ON THE USE OF PSYCHOLOGICAL TESTS TO DETERMINE ASYLUM SEEKERS' SEXUAL ORIENTATION AND THE IMPACT ON THE RIGHT TO PRIVATE LIFE (CASE C-473/16, 25 JANUARY 2018)
}

\author{
Valerie De Bruyckere*
}

Summary: This paper covers the problems and dynamics that LGBTQI (Lesbian, Gay, Bisexual, Queer and Intersex) asylum seekers face when they leave their country of origin and enter countries within the European Union. Only a small percentage of people that claim asylum on the basis of reasonable fear of persecution because of sexual orientation are granted asylum within these EU Member States, or some other form of international protection.

The paper scans the relevant legislation that is supposed to protect asylum seekers in general and covers the three most important cases of the Court of Justice of the European Union (CJEU) on the treatment and assessment of asylum applications on the basis of fear of persecution because of sexual orientation. The case at hand needs to be seen within this general framework as we know it so far.

F v Hungary concerns the case of a Nigerian national claiming asylum on the basis of fear of persecution in his country of origin because of his homosexuality. To determine his general credibility, the Hungarian determining authorities subjected $F$ to three different psychological tests. However, the psychological experts could not confirm or deny F's sexual orientation based on these tests. Consequently, the determining authorities decided that his general credibility could not be established and his claim for asylum was denied.

The Hungarian Appeal Court requested a preliminary ruling before the CJEU. The Court ruled that in these cases it is not always necessary to determine the sexual orientation of an applicant. The CJEU stressed that, when assessing an asylum application, it does not matter whether or not an applicant actually identifies with the particular social group that attracts persecution. Scientific reports from medical, psychological or social experts can certainly be of value throughout the asylum application assessment, but determining authorities cannot

\footnotetext{
"Valérie De Bruyckere (https://orcid.org/0000-0001-7713-032X) studied at the University of Antwerp and the University of Zagreb. She graduated in 2018 with a major in Public Law. She is currently working as a lawyer and specialises in administrative law. DOI: 10.3935/cyelp.14.2018.311.
} 
be bound by such expert reports. Every case should undergo an in concreto assessment, taking into account the individual circumstances and with respect for human dignity, the right to respect for private and family life, and the right to an effective remedy as guaranteed by Articles 1, 7 and 47 of the EU Charter. Every interference with these rights should be in line with the proportionality principle.

Finally, some suggestions are made to shape a future strategy and the development of asylum application assessment.

\section{Introduction}

'Staying alive.' Probably the first and only thing on asylum seekers' minds. There is no reason to believe that this would be any different for gay asylum seekers. Sexual orientation appears to be the most difficult ground for asylum to prove. Often there is no material evidence, or it cannot be relied upon, and the determining authorities are left to assess every case based on statements and declarations of the applicants themselves. These asylum seekers come from countries where they face persecution, social exclusion or even the death penalty. For many lesbian, gay, bisexual, transgender, queer and intersex (hereafter: LGBTQI) asylum seekers, talking about intimate experiences and sexuality is often difficult and many of them do not mention their sexual orientation as a reason until late in the asylum procedure, causing the determining authorities to question the sincerity of their statements and their general credibility.

Dublin III entered into force in July 2013 and aims to provide procedures for all Member States to protect asylum seekers and improve the efficiency of the asylum application process. However, the existing legislation has so far failed to provide specific protection and safeguards for LGBTQI asylum seekers. These asylum seekers are especially vulnerable because of social stigma, a lack of acceptance, and a general incomprehensive attitude in some societies. Both these asylum seekers and the human rights organisations representing them have become more vocal about some disturbing experiences and Member States' malpractices when assessing asylum applications.

Over the last few years, the Court of Justice of the European Union (hereinafter: CJEU, or the Court) has had a few opportunities to shed light on how asylum assessment should be conducted. In 2014, in a case known as $A, B$ and $C$, the CJEU ruled on a preliminary reference from the Netherlands. The Court found that allowing evidence of homosexual acts from tests or films would violate human dignity. The events that sparked the judgment were the cases of three asylum seekers whose requests for asylum were denied. After being rejected, they applied for 
asylum a second time based on their fear of persecution for their sexual orientation in their country of origin. With their application, they provided videos of intimate acts performed on a person of the same sex or expressed their willingness to participate in tests or perform a homosexual act to prove the truthfulness of their sexuality. All three applications were again dismissed for lack of credibility. The Court ruled that EU law precludes national authorities from accepting such evidence with the view of establishing the applicant's sexuality. ${ }^{1}$ Besides the fact that such evidence cannot be seen as valuable to assess an asylum application, it is irreconcilable with human dignity as guaranteed by Article 1 of the Charter of Fundamental Rights. The Court has also recognised and condemned the practice of the determining authorities relying heavily or even solely on certain stereotypical characteristics of LGBTQI people and, in doing so, ignoring the individual situation and personal circumstances, rendering an in concreto assessment impossible.

More recently, on 25 January 2018, the CJEU ruled on the use of Hungary's psychological tests to determine asylum seekers' sexual orientation. This judgment is the topic of this case comment, and opens up broader discussion on the general treatment of asylum seekers across the European Union and discrimination based on their sexual orientation.

This paper will focus on the use of psychological tests to determine the sexual orientation of asylum seekers and the CJEU's view on the potential danger of using such tests in asylum application procedures. In order to better analyse the meaning of the case at hand, it is important to first consider the principles and methods that are currently used by Member States.

Classically, the term 'LGBT' is used throughout legal literature. In this case comment, however, the term 'LGBTQI' will be used, making sure also that people who identify as queer or intersexual are included. I believe it is important to include all categories of the sexuality spectrum that are at risk of facing persecution in their countries of origin, since the protection of all these asylum seekers' personal integrity is paramount and all their applications should be assessed with the same level of scrutiny and attention. Other categories, such as asexual people, are not included in the LGBTQI categorisation.

The aim of this paper is to provide an overview of the Court's case law determining the favourable and unfavourable methods in assessing asylum applications based on sexual orientation. A correct and careful assessment of such applications ensures that due consideration is given

\footnotetext{
1 Case C-148/13 A, B and C v Staatssecretaris van Veiligheid en Justitie ECLI:EU:C:2014:
} 2406. 
to the applicants' rights to private life, and the personal situation and circumstances are taken into account.

\section{Asylum applications based on sexual orientation and their assessment within the European Union}

\subsection{General guidelines and practices}

The way the determining authorities investigate and assess asylum applications differs among Member States. Generally, the procedure consists of a two-tier investigation where, firstly, open questions are asked about the applicant's alleged sexual orientation to establish the facts of the individual case. Only after that are more general questions asked to establish overall credibility. ${ }^{2}$ In some countries, however, applicants are subjected to psychological tests. Refugees who request asylum based on their sexual orientation need to prove three things. Firstly, that they are a member of an LGBTQI society. Secondly, that they fear persecution in their country of origin on the grounds of their sexuality. And thirdly, that their fear is well founded. A few of these proofs are certainly an issue and may in some cases be a violation of human rights. Indeed, it was also these very issues that were brought before the Court and will be discussed further in this case note.

In 2017, the UK's Home Office came under fire after it released experimental data on the asylum outcomes of applicants coming from countries that are considered to be amongst the most homophobic in the world. It was reported that only 63 of 331 applicants from Nigeria were granted asylum based on their sexual orientation. Not a single applicant of the 82 Indian or 48 Sri Lankan applicants was granted asylum. ${ }^{3}$

Similar trends are detected in countries like the Netherlands, despite its liberal and progressive tradition and mindset. Stories emerge about individuals being refused asylum based on their sexual orientation because they are 'not gay enough', because of the applicant being married in the past or having children and therefore not possibly being able to be regarded as a member of the LGBTQI community. ${ }^{4}$

\footnotetext{
2 UNHCR, 'Handbook and Guidelines on Procedures and Criteria for Determining Refugee Status under the 1951 Convention and the 1967 Protocol Relating to the Status of Refugees' (UNHCR 2011).

3 Nick Duffy, 'The UK Has Rejected Thousands of Gay Asylum Seekers' (Pink News, 30 November 2017) <www.pinknews.co.uk/2017/11/30/the-uk-has-rejected-thousands-ofgay-asylum-seekers> accessed 19 May 2018.

4 Sarah French Brennan, 'LGBT Asylum Seekers Struggle to Find Safety - Even in a Progressive Country Like the Netherlands (Quartz, 5 July 2017) <https://qz.com/1021301/ lgbt-asylum-seekers-struggle-to-find-safety-even-in-a-progressive-country-like-the-netherlands/> accessed 20 May 2018.
} 
In Belgium, asylum applications based on sexual orientation make up approximately $20 \%$ of all asylum claims, but only one out in five applicants in this category is granted asylum or some form of international protection. $^{5}$

There is little reason to believe that asylum applications based on sexual orientation are more successful. ${ }^{6}$ An important factor cultivating these malpractices is that many determining authorities still rely on the classical stereotypes associated with LGBTQI people. Relying on the behaviour generally attributed to people with a certain sexual orientation to make legally binding decisions is as absurd as it is dangerous. Relying on the idea that the sexual orientation of an asylum seeker can only be taken seriously when that person demonstrates a certain behaviour generally associated with homosexual people means that an important proportion of LGBTQI asylum seekers are left out. The determining authorities tend to treat asylum applications of non-effeminate gays or of lesbians who do not behave in a masculine way with caution. Bisexuals even risk being excluded from international protection completely. This is also the case for LGBTQI applicants who have been married in the past or those who have children. They face even more difficulties proving their reasonable fear of persecution in their home country.

\subsection{Common European Asylum System}

Since 1999 the European Union has been trying to develop a Common European Asylum System (hereinafter: CEAS) and has adopted several legislative measures to ensure and harmonise minimum standards for asylum. Its creation developed over time and is founded on three pillars:

i) Bringing more harmonisation to standards of protection by further aligning the EU States' asylum legislation;

ii) Effective and well-supported practical cooperation;

iii) Increased solidarity and a sense of responsibility between EU States, and between EU and non-EU countries. ${ }^{7}$

\footnotetext{
5 Commission, 'EMN Ad-Hoc Query on NL AHQ on National Asylum Policies Regarding LGBT-Asylum Seekers' available at <https://ec.europa.eu/home-affairs/sites/homeaffairs/files/what-we-do/networks/european_migration_network/reports/docs/ad-hocqueries/ad-hoc-queries-2016.1061_-_nl_ahq_on_national_asylum_policies_regarding_ lgbt-asylum_seekers.pdf> accessed 14 June 2018.

6 Johannes Lukas Gartner '(In)credibly Queer: Sexuality-based Asylum in the European Union' in Anthony Chase (ed), Transatlantic Perspectives on Diplomacy and Diversity (Humanity in Action Press 2015) <www.humanityinaction.org/knowledgebase/578-in-credibly-queer-sexuality-based-asylum-in-the-european-union> accessed 2 July 2018.

7 European Commission, 'Common European Asylum System' (European Commission, 2 July 2018) <https://ec.europa.eu/home-affairs/what-we-do/policies/asylum_en> accessed 1 July 2018.
} 
Even though the European Union has already adopted a multitude of legislation to attain these goals, no specific directive or regulation to protect LGBTQI asylum seekers or to regulate the assessment of asylum applications based on sexuality has been drafted. This legal gap is regrettable, since clarity in this domain would greatly benefit the vulnerable group of LGBTQI asylum seekers across the European Union.

On a few points, states within the European Union fail to comply with the legal standards set out by both European and international human rights law when assessing asylum applications based on sexual orientation. ${ }^{8}$ AG Sharpston also remarked that neither the Procedures Directive, the Geneva Convention, nor the Charter provides specific rules on how the credibility of asylum seekers should be assessed. ${ }^{9}$

\subsection{Outlawing the 'discretion requirement'}

It was only in 2013 that the Court rightfully banned determining authorities from all Member States from returning asylum claimants to their respective countries of origin, telling them to be 'discreet' about their sexual orientation in the $X, Y$ and $Z$ case. ${ }^{10}$

The Court then stated that sexual orientation asylum applicants need to fulfil two criteria:

i) The social recognition test, where membership of a group socially recognisable in the country of origin is proven; and

ii) The fundamental characteristic test, where applicants need to show that the recognition of their sexual identity as a characteristic is so fundamental to their identity that one should not have to renounce it.

On the same note, the Court determined that the criminalisation of same-sex conduct in the country of origin does not in itself constitute an act of persecution. The applicant needs to show a specific and reasonable fear of persecution. The principles set by the Court in this judgment are sometimes considered not being in line with the UNHCR guidelines and reflect a strict interpretation of EU law. ${ }^{11}$

\footnotetext{
8 Sabine Jansen and Thomas Spijkerboer, Fleeing Homophobia (COC Nederland, 2011) $<$ http://dare.ubvu.vu.nl/bitstream/handle/1871/23884/Fleeing\%20Homophobia\%20report\%20EN.pdf?sequence=2> accessed 11 December 2018 .

${ }_{9}$ Case C-148/13A,BandCvStaatssecretarisvan VeiligheidenJustitieECLI:EU:C:2014:2111, Opinion of AG Sharpston, para 32.

10 Case C-199/12 to C-201/12 X, Y and $Z v$ Minister voor Immigratie en Asiel ECLI:EU:C:2013:720.

11 Nuno Ferreira and Denise Venturi, Testing the Untestable: The CJEU's Decision in Case C-473/16, F v Bevàndorlàsi és Àllampolgàrsàgi Hivatal (European Database of Asylum
} 


\subsection{Four types of unacceptable methods of assessment}

In the case $A, B$ and $C$, the CJEU gave binding guidelines on how asylum applications based on sexual orientations should be examined. The Court clarifies that statements of the applicants are a starting point for the procedure. Determining authorities are not required to accept claims about a certain sexual orientation without further investigation. Similarly, just like asylum applications on other grounds, Member States are expected to fully and carefully consider the truthfulness of statements and establish the general credibility of the applicants.

The Court states that Member States' methods of assessment should be in conformity with the fundamental rights and freedoms as guaranteed by the Charter, more specifically respect for human dignity ${ }^{12}$ and the right to private life. ${ }^{13}$

At the same time the Court also developed four principles on how Member States should adjust their assessment procedures to be in accordance with Article 4 of Directive 2004/83. ${ }^{14}$

Firstly, the CJEU states that:

assessments based on questioning as to the knowledge on the part of the applicant for asylum concerned of organisations for the protection of the rights of homosexuals and the details of those organisations, such questioning suggests (...) that the authorities base their assessments on stereotyped notions as to the behaviour of homosexuals and not on the basis of the specific situation of each applicant for asylum. ${ }^{15}$

An assessment based on stereotyped notions fails to comply with Article 4(3) of Directive 2004/83, requiring Member States to carry out assessments that take account of the individual position and personal circumstances of the applicant. The Court acknowledges that questions

Law, 28 June 2018) <http://www.asylumlawdatabase.eu/en/journal/testing-untestable-cjeu's-decision-case-c-47316-f-v-bevándorlási-és-állampolgársági-hivatal> accessed 30 September 2018.

12 Charter of Fundamental Rights of the European Union, Art 1.

13 Charter of Fundamental Rights of the European Union, Art 7.

14 Art 4 of the Council Directive 2004/83/EC of 29 April 2004 on minimum standards for the qualification and status of third country nationals or stateless persons as refugees or as persons who otherwise need international protection and the content of the protection granted [2004] OJ L304/12 contained the requirements for Member States for the assessment of facts and circumstances. At present, the Directive is no longer in force, but Art 4 was re-adopted verbatim by Art 4 of Directive 2011/95/EU of the European Parliament and of the Council of 13 December 2011 on standards of the qualification of third-country nationals or stateless persons as beneficiaries of international protection, for a uniform status for refugees or for persons eligible for subsidiary protection, and for the content of the protection granted [2011] OJ L337/9.

15 A, B and C (n 1) para 60. 
based on stereotyped characteristics may be a useful element at the disposal of competent authorities, but an assessment of applications in granting refugee status on the basis solely of stereotyped notions associated with homosexuals does not satisfy the requirements of the relevant provisions in that it does not allow authorities to take account of the individual situation and personal circumstances of the applicant for asylum. When an applicant is incapable of answering such questions, the determining authority cannot simply decide that the applicant lacks credibility. ${ }^{16}$

Secondly, the Court finds that questions concerning details of the sexual practices of that applicant are contrary to the applicant's right to respect for private and family life as guaranteed in Article 7 of the Charter. ${ }^{17}$

Thirdly, the Court renounces the use of tests to prove homosexuality or the production of evidence such as films of intimate acts by the applicants. Such evidence does not necessarily have probative value, and the Court finds that such evidence by its nature would infringe human dignity as guaranteed by Article 1 of the Charter. National authorities allowing homosexual acts to be performed and the submission of the applicants to possible 'tests' in order to demonstrate their sexuality, or the production of films of their intimate acts, are not to be allowed under any circumstances. ${ }^{18}$ The Court rightly reminds us that allowing or authorising such evidence would have the undesirable effect that other applicants would feel the need to provide similar evidence and would de facto lead to requiring applicants to provide it. ${ }^{19}$

By including the prohibition of tests or the production of video evidence to prove homosexuality, the Court not only quashes the use of the type of evidence that lay at the origin of the case, but also denounces the use of so-called 'phallometric tests', which were at the time used in some Member States, like the Czech Republic and Slovakia. ${ }^{20}$ These tests consisted of verifying the physical reaction of gay asylum seekers to heterosexual pornographic material. Only when a person did not show a reaction to the visual representations of heterosexual sex were his claims about his homosexuality considered proven. Even though widely used in the past, these tests were considered highly inaccurate and speculative. ${ }^{21}$

\footnotetext{
16 ibid, paras 61-63.

17 ibid, para 64.

18 ibid, para 65.

19 ibid, para 66.

20 Nikolaj Nielsen, 'EU Court Strikes Down Gay Asylum Tests' (EUobserver, 2 December 2014) <https://euobserver.com/justice/126758> accessed 14 June 2018.

${ }^{21}$ European Union Agency for Fundamental Rights, "The Practice of "Phallometric Testing" for Gay Asylum Seekers' (FRA, 9 December 2010) <http://fra.europa.eu/en/news/2011/ practice-phallometric-testing-gay-asylum-seekers> accessed 14 June 2018.
} 
Fourthly, the Court specified that the determining authorities must have regard to the sensitive nature of questions relating to a person's personal identity and, in particular, his sexuality. It cannot be concluded that an applicant lacks credibility simply because that person did not declare his homosexuality at the outset of his application. Member States must make sure that the vulnerability of applicants is taken into account, together with the personal and general circumstances surrounding the application. Reticence in revealing intimate aspects of a person's life cannot entail any negative consequences for his asylum application. ${ }^{22}$

\section{The CJEU's view on the use of psychological tests in determining asylum seekers sexual orientation}

\subsection{Circumstances and questions before the Court}

The case ${ }^{23}$ was brought before the CJEU after F, a Nigerian national who claimed to have a well-founded fear of persecution in his country of origin on account of his homosexuality, was denied asylum by the Hungarian Office for Immigration and Citizenship. Although his statements were not fundamentally contradictory, it was concluded that he lacked credibility based on a psychologist's report that it was not possible to confirm F's sexual orientation. It is important to keep in mind that the report determined that it was not possible to determine F's sexual orientation, but also did not deny that the applicant was gay. The question arises whether providing such proof is even possible.

The psychological report was based on three different psychological tests. Firstly, the 'Draw-A-Person-In-The-Rain' test is a personality and cognitive test generally used for children and adolescents, making the subject draw a person in the rain. Depending on different aspects, such as the size of the umbrella and the position of the person, psychologists would be able to determine personal traits and intelligence. For the Rorschach test, the second test, psychologists extract subjects' perceptions based on inkblots. And for the third, the Szondi test, psychologists would be able to identify the most important human drive and personality traits by making the subject look at eight pictures and have them point out the person they would not want to meet after sundown. No questions about sexual habits were asked and the applicant was not subjected to a physical examination. It is not hard to believe that these tests are generally believed to be ineffective in determining sexual orientation or even other personality traits. ${ }^{24}$

\footnotetext{
$22 \quad A, B$ and $C$ (n 1), paras 67-71.

${ }^{23}$ Case C-473/16 F v Bevándorlási és Állampolgársági Hivatal ECLI:EU:C:2018:36.

24 Scott O Lilienfeld, James M. Wood and Howard N. Garb, 'What's Wrong with This Picture?' (Scientific American, May 2001) <www.psychologicalscience.org/newsresearch/publications/journals/sa1_2.pdf> accessed on 30 September 2018.
} 
When an applicant has made a genuine effort to provide evidence and establish his general credibility, but there is still a lack of evidence to substantiate his story, the determining authority should consider the benefit of the doubt. The applicant has the right to enjoy this benefit when no fundamental contradiction in his story can be found. ${ }^{25}$ Clearly, this principle was not applied in F's case.

After having his asylum application rejected, the applicant appealed before the Szeged Administrative Court, which referred several questions to the CJEU for a preliminary ruling. The main question was whether Article 4 of Council Directive 2004/83/EC ${ }^{26}$ on the assessments of facts and circumstances, in the light of Article 1 of the Charter of Fundamental Rights of the European Union, precludes forensic psychologists' expert opinions based on projective personality tests from being used in asylum adjudication relating to LGBTQI claimants when such tests do not enquire about the applicants' sexual habits and do not entail a physical examination. If this possibility is precluded, the appeal court asked whether asylum authorities are prevented from examining with these 'expert methods' the truthfulness of such international protection claims.

\subsection{Relevant legal context}

The applicant's claim was based on the right to private life as guaranteed by Article 8(1) ECHR and several other EU law provisions. Additionally, the applicant also claimed that the determining authority should be a quasi-judicial or administrative body responsible for an appropriate examination of applications for asylum. The Member States must ensure that personal interviews allow applicants to present the grounds for their applications in a comprehensive manner and that personal or general circumstances are considered, including the applicant's cultural origin or vulnerability. The assessment should be carried out on an individual basis and should take a multitude of criteria into account (all relevant facts, statements, the individual position, personal circumstances, activities and whether the country of origin provides protection for the applicant). When assessing if an applicant has a well-founded fear of persecution, it is immaterial whether the

\footnotetext{
25 United Nations High Commissioner for Refugees (UNHCR), 'Handbook and Guidelines on Procedures and Criteria for Determining Refugee Status under the 1951 Convention and the 1967 Protocol Relating to the Status of Refugees' (UNHCR 2011).

26 Council Directive 2004/83/EC of 29 April 2004 on minimum standards for the qualification and status of third country nationals or stateless persons as refugees or as persons who otherwise need international protection and the content of the protection granted [2004] OJ L304/12.
} 
applicant actually possesses the characteristic that attracts the persecution. $^{27}$

Besides, the personnel examining applications and taking decisions have the possibility to seek advice from experts, for example for medical, cultural, religious and gender issues. An applicant must have the right to an effective remedy against a decision that denies refugee status or similar subsidiary protection. ${ }^{28}$

\subsection{LGBTQI rights in Nigeria}

It is easy to say that LGBTQI rights in Nigeria do not exist. Sections 215-217 of the Nigerian Criminal Code Act, together with the 2013 SameSex Marriage (Prohibition) Act, criminalises 'acts against the order of nature' committed by people who have sexual relations with a person of the same sex. The maximum penalty is 14 years of imprisonment.

In the northern parts of Nigeria, LGBTQI people are treated even worse. Sharia law is applicable and criminalises sexual acts between people of the same sex. The maximum penalty for these activities between men is the death penalty by stoning, whereas the maximum penalty for women is whipping and/or imprisonment. ${ }^{29}$

These circumstances need to be taken into account when assessing an asylum application based on sexual orientation. The fact that there was no reference to this information in F's case is alarming.

\subsection{Judgment}

The CJEU first takes the relevant legal provisions into account and acknowledges that the determining authorities should have regard for the context and circumstances. There is no doubt that having a sexual orientation can constitute membership of a particular social group that is perceived by the surrounding society as being different and therefore can possibly be considered a threat. It is important that the CJEU also considers that it does not actually matter whether the applicant identi-

\footnotetext{
${ }_{27}$ Council Directive 2005/85/EC of 1 December 2005 on minimum standards on procedures in Member States for granting and withdrawing refugee status [2005] OJ L326/13, Arts 2(e), 4(1), 8(2), 10(2), 13(3).

28 Directive 2013/32/EU of the European Parliament and of the Council of 26 June 2013 on common procedures for granting and withdrawing international protection [2013] OJ L180/60, Art 10(3), 46(1).

29 Aengus Carroll and Lucas Ramón Mendos, 'State-sponsored Homophobia - A World Survey of Sexual Orientation Laws: Criminalisation, Protection and Recognition' (ILGA, 2017 <https://ilga.org/downloads/2017/ILGA_State_Sponsored_Homophobia_2017_WEB.pdf> accessed 30 September 2018.
} 
fies with the social group that attracts persecution. The Court stressed that it is possible for a person to be considered a member of a particular social group when the characteristic is simply attributed to the person by the actor(s) of the persecution. It is therefore not always even necessary to assess the applicant's sexual orientation, since it is possible that non-heterosexual orientation is simply attributed or perceived by the surrounding society of the applicant. ${ }^{30}$

Expert reports should, however, not be excluded from the process of assessment to determine the applicant's actual need for asylum or other protection and can even prove to be useful. Nevertheless, the procedures used by the determining authorities should be in line with EU law and respect any applicant's fundamental rights and freedoms, more specifically Article 1 (human dignity), Article 7 (right to respect for private and family life) and Article 47 (right to effective remedy) of the EU Charter. Moreover, it is for these determining authorities alone to examine and decide on asylum applications. They cannot be bound, either de facto or de lege, by conclusions from expert reports relating to sexual orientation. National determining authorities are to take ultimate responsibility for an individual and in concreto assessment of the situation and cannot put this responsibility onto (psychological) experts. ${ }^{31}$

The CJEU found interference with the applicant's private life, and states that such interference should be proportionate, ie the measures should not exceed what is appropriate and necessary to attain the legitimate objectives pursued by legislation. The determining authorities should assess whether psychologists' reports are appropriate and necessary after considering the individual circumstances. The Court found that it is apparent that the seriousness of the interference in this case exceeded what was needed to assess the applicant's fear of persecution. It goes on to stress that national authorities should focus on providing the necessary training and skills for asylum case workers to assess all personal circumstances in asylum applications, including matters of sexual orientation. ${ }^{32}$

Advocate General Wahl had already raised the importance of consent in examining asylum applications in his Opinion. Wahl states that an applicant should have sufficient knowledge of psychological examinations and that a refusal to undergo these tests should be respected. ${ }^{33}$ The CJEU adds that a refusal to undergo such examinations, when care is

\footnotetext{
30 Fv Bevándorlási és Állampolgársági Hivatal (n 23) paras 31-32.

31 ibid, para 40-42.

32 ibid, para 66-67.

33 Case C-473/16 Fv Bevándorlási és Állampolgársági Hivatal ECLI:EU:C:2017:739, Opinion of AG Wahl, para 43.
} 
taken to respect the applicant's private life and human dignity, may have certain negative consequences. ${ }^{34}$ This is a very disturbing declaration from the Court, especially taking into account that asylum applicants already undergo the inevitable pressure to undergo any tests. In my opinion, an applicant's refusal to undergo any psychological or other test should not have any negative consequences on establishing his general credibility, provided that the applicant is otherwise cooperative and willing to provide evidence of his individual circumstances. Other authors agree that when an asylum seeker refuses to participate in a test with no probative value, this may lead to the refusal of their application, which is considered a highly disproportionate and unfair outcome. ${ }^{35}$

Making a final judgment based on the above-mentioned reasons, the CJEU acknowledges the considerations that ILGA-Europe and other similar human rights NGOs have been making for years. ${ }^{36}$ When an applicant's statement is consistent and plausible, and the applicant genuinely tries to substantiate his application, it may not be necessary to actually determine or confirm the applicant's sexuality. When an asylum applicant is cooperative and gives a valid and satisfactory explanation for any lack of material evidence for some elements of his circumstances, the applicant should be granted international protection at the earliest possible time.

The issue remaining is that the Court still does not offer any positive guidelines as to how the national determining authorities should deal with evidence, and it still does not recognise the importance of self-declared sexual orientation by asylum applicants. ${ }^{37}$ Unfortunately, the Court remains careful and refrains from giving stricter guidelines, but

${ }^{34}$ F v Bevándorlási és Állampolgársági Hivatal (n 23) paras 52-53.

35 Nuno Ferreira and Denise Venturi, 'Tell Me What You See and I'll Tell You If You're Gay: Analysing the Advocate-General's Opinion in Case C-473/16 F v Bevándorlási és Állampolgársági Hivatal' (EU Immigration and Asylum Law and Policy, 24 November 2017) <http:// eumigrationlawblog.eu/tell-me-what-you-see-and-ill-tell-you-if-youre-gay-analysing-theadvocate-generals-opinion-in-case-c-47316-f-v-bevandorlasi-es-allampolgarsagi-hivatal/> accessed 30 September 2018.

36 Sabine Jansen, 'Good Practices' (ILGA Europe, 2014) <www.refworld.org/pdfid/5433a8124.pdf> accessed 18 June 2018. Already in May 2014, ILGA-Europe released a report stating that they 'acknowledge that LGBTI asylum authorities need to assess the general credibility of an applicant's story in relation to the well-foundedness of the fear of persecution. However, this assessment differs from testing one's sexual orientation or gender identity. ILGA-Europe is of the opinion that the assessment should acknowledge the self-identification of the person concerned and focus on the persecution this person has experienced or fears'.

37 Nuno Ferreira and Denise Venturi, 'Testing the Untestable: The CJEU's Decision in Case C-473/16, F v Bevàndorlàsi és Àllampolgàrsàgi Hivatal' (European Database of Asylum Law, 28 June 2018) <http://www.asylumlawdatabase.eu/en/journal/testing-untestable-cjeu's-decision-case-c-47316-f-v-bevándorlási-és-állampolgársági-hivatal> accessed 30 September 2018. 
overall tries to promote fair and lawful asylum decision-making procedures throughout the EU. In my opinion, however, it is time for the Court to establish more stringent rules for national determining authorities. But in order for it to do so, the national courts requesting preliminary rulings must shape their questions in such a way that they give the Court the possibility to do this. Domestic courts currently have a wide margin of appreciation in this matter, but it can be argued that it is unwise to offer domestic authorities such leeway in asylum cases based on sexual orientation since there is generally no correct assessment. ${ }^{38}$

\section{What next?}

\subsection{A strategy to shape the future of sexual orientation asylum cases in the EU}

There are three aspects that are important in shaping the future of determining sexual asylum claims: training, guidance, and quality control. The combination of these three aspects are the only way forward to optimise asylum assessment throughout the European Union and provide adequate protection to the applicants that need international protection.

Firstly, training is an important tool for determining authorities to correctly assess all types of asylum claims. It provides caseworkers with a sound base of experience and gives them the knowledge, tools, attitude and practical skills to adequately assess the applicant's situation. ${ }^{39}$ The topic remains a complex and difficult area and sexual orientation remains a sensitive issue. Caseworkers applying correct and sensible training can make a difference at all stages of the asylum application assessment.

Secondly, the importance and involvement of (LGBTQI) refugees should not be underestimated. Former and current refugees and sexual orientation experts can provide the necessary guidance to help determining authorities to address the needs of LGBTQI asylum seekers more effectively. They can offer this advice and guidance in a comprehensive and effective way. ${ }^{40}$ It is important to offer more than just prescriptive

\footnotetext{
38 Ferreira and Venturi (n 35).

39 ORAM, 'Training on Sexual and Gender Minorities: What Refugee Professions Need to Know and Do' (ORAM, 2015) <http://oramrefugee.org/wp-content/uploads/2016/05/ Sample-Training-Slides-English.pdf> accessed 30 September 2018.

40 US Citizen and Immigration Services, 'Guidance for Adjudicating Lesbian, Gay, Bisexual, Transgender and Intersex (LGBTI) Refugee and Asylum Claims' (US Department of Homeland Security, 2011) <www.uscis.gov/sites/default/files/USCIS/Humanitarian/Refugees $\% 20 \% 26 \% 20$ Asylum/Asylum/Asylum $\% 20$ Native $\% 20$ Documents $\% 20$ and $\% 20$ Static\%20Files/RAIO-Training-March-2012.pdf> accessed 30 September 2018.
} 
lists and questions, but also to give positive guidance to establish what aspects should be discussed and how interviews should be conducted to provide optimal protection for the people who need it.

Finally, a reliable quality control system would greatly benefit the determining authorities across the European Union and provide caseworkers to learn from the best practices of others. This would allow the identification of inappropriate evidentiary practices and make sure these authorities can improve their assessment techniques. ${ }^{41}$

It should no longer be the case that LGBTQI asylum seekers feel that they are expected to present themselves in a certain way to fit more into the global LGBTQI image. ${ }^{42}$ The above-mentioned training, guidance and control could make the difference in many asylum seekers cases. Furthermore, it is generally agreed that sexual orientation is a complex matter and is deeply entwined with the identity of an applicant. Therefore, an assessment should take place with respect for the right to private life, as guaranteed by Article $7 .{ }^{43}$

\subsection{Analysis of F's case}

The CJEU obviously values an in concreto assessment of every asylum application. Expert (psychological) reports can be used in assessing an applicant's credibility and personal circumstances. These tests should, however, respect EU law and every applicant's fundamental rights and freedoms. Such reports can only give an indication of sexual orientation. When the authorities base their decision solely on expert reports, it shows an improper examination of the applications since no weight is given to other factors or an applicant's general credibility.

It is now up to the Hungarian authorities to further decide on F's case. Logically, they will not only have to consider the recent judgment of the CJEU, but they will also have to have consideration for the previous case law by applying both the social recognition test and the fundamental characteristic test. ${ }^{44}$

\footnotetext{
${ }^{41}$ John Vine, 'An Investigation into the Home Office's Handling of Asylum Claims Made on the Grounds of Sexual Orientation March-June 2014' (Independent Chief Inspector of Borders and Immigration, 2014) <https://assets.publishing.service.gov.uk/government/ uploads/system/uploads/attachment_data/file/547330/Investigation-into-the-Handling-of-Asylum-Claims_Oct_2014.pdf> accessed 30 September 2018.

42 Johannes Lukas Gartner, (In)credibly Queer: Sexuality-Based Asylum in the European Union (Humanity in Action 2015).

43 A, B and C, Opinion of AG Sharpston (n 9) para 38.

${ }^{44} X, Y$ and $Z$ (n 10).
} 
The social recognition test entails that the Hungarian Appeals Court will need to check F's membership of a group socially recognisable in the country of origin. Obviously, the Appeals Court will need to consider the specific circumstances of the case. Then, there is also an abundance of information on the treatment of LGBTQI people in Nigeria that needs to be taken into account by the Court. ${ }^{45}$

Secondly, the fundamental characteristic test requires the recognition of a certain sexual identity as a characteristic so fundamental to a person's identity that the persons concerned should not have to renounce it.

\section{Conclusion}

It seems that even now the Court refrains from providing more guidance on how Member States should be assessing asylum claims based on sexual orientation. There is a desperate need for clearer guidelines on how asylum applications should be assessed, and especially in the case of LGBTQI applicants. While the European legislation lags behind in filling these legal gaps, this case was an excellent opportunity for the CJEU to further develop more binding principles for Member States, and by extension for their determining authorities.

There is no doubt, however, that the CJEU's decision will have an impact on all Member States and their asylum examination procedures. As the above-mentioned examples of other Member States show, there is still a lot of work to do.

It is, however, refreshing to see that some Member States are picking up on this individual approach and are encouraging their immigration officers to be considerate of gender-specific issues and individual circumstances. ${ }^{46}$ The CJEU also considers that it does not matter whether an applicant actually identifies as homosexual. What matters is how the applicant is perceived by the surrounding society and the potential consequences that perception may have for his or her physical integrity, which can be the grounds for a well-founded fear of persecution. The determining authorities should be assessing the general credibility and circumstances of an applicant instead of trying to determine the actual sexual orientation.

Overall, the CJEU has again highlighted some important aspects of how asylum applications based on sexual orientation should be consid-

\footnotetext{
45 For example, in Carroll and Mendos (n 29).

46 See, for example, UK Home Office, 'Staff Guide on Gender Issues in the Asylum Claim' (UK Home Office, 10 April 2018) <https://assets.publishing.service.gov.uk/government/ uploads/system/uploads/attachment_data/file/699703/gender-issues-in-the-asylumclaim-v3.pdf> accessed 20 May 2018.
} 
ered, providing the various determining authorities in all Member States with a clearer vision on how they should conduct these assessments.

It appears, however, that the use of (psychological) tests in these assessments remains controversial. This becomes apparent when comparing the Opinion of AG Wahl in the case at hand and AG Sharpston's Opinion in $A, B$ and $C$, in which the latter stated:

Since homosexuality is not a medical condition, any purported medical test applied to determine an applicant's sexual orientation could not, in my view, be considered to be consistent with Article 3 of the Charter. It would also fail the proportionality requirement (Article 52(1)) in relation to a violation of the right to privacy and family life because, by definition, such a test cannot achieve the objective of establishing an individual's sexual orientation. It follows that medical tests cannot be used for the purpose of establishing an applicant's credibility, as they infringe Articles 3 and 7 of the Charter. [...] Even if an applicant consents to any of the three practices (medical examinations, intrusive questioning, or providing explicit evidence), such consent does not change my analysis. The applicant's consent to a medical test for something (homosexuality) that is not a recognised medical condition (i) cannot remedy a violation of Article 3 of the Charter, (ii) would not increase the probative value of any evidence obtained and (iii) cannot render such a limitation of the rights guaranteed by Article 7 of the Charter proportionate for the purposes of Article 52(1). Furthermore, I also entertain serious doubts as to whether an applicant, who is the vulnerable party in the procedure of applying for refugee status, could really be deemed to have given fully free and informed consent to the competent national authorities in such circumstances. ${ }^{47}$

It occurs to me that the Court can do better and has an important role in shaping future assessments of refugee applications. It should consider taking bolder and more daring positions, like the Opinion of AG Sharpston, in order to better protect refugees across the European Union. May the Court find the will and strength to do so in the next case!

Unfortunately, the political climate in Hungary does not seem to show a welcoming climate for refugees at all. A recent reflection of this evolution was made painfully clear in the light of the UN Migration Pact. The Pact was adopted in Marrakech on 10 December 2018 and voted for by the UN General Assembly on 19 December in New York. The Pact gathered an overwhelming 152 votes in favour with only 5 countries voting against. Nevertheless, the political climate in the majority of countries was divided in the weeks running up to the gathering in Marrakech. Hungary was one of the first countries to officially state that it would not

$47 \quad A, B$ and $C$, Opinion of AG Sharpston (n 9), paras 61 and 67. 
sign the Pact. Previously, Hungary expressed its opposition to refugee quotas, designed to share the burden of Mediterranean countries such as Italy, Greece and Spain, where most immigrants from Turkey, Syria and African countries arrive. This stance was sadly followed by Poland, the Czech Republic and Austria and also made other countries doubt whether or not to sign the UN Migration Pact. The reluctance to sign even a non-binding instrument is appalling and is typical of the current political climate. We can only hope that the efforts of human rights organisations, the CJEU, and all those working with migrants and refugees are not in vain, and that we can continue to grow towards a more understanding European Union. 